\title{
Analisis Pola Pengambilan Mata Kuliah dan Kinerja Mahasiswa Tiap Angkatan dengan Menggunakan Teknik Process Mining
}

\author{
Satrio Adi Priyambada dan Mahendrawathi ER., S.T., M.Sc., Ph.D. \\ Jurusan Sistem Informasi, Fakultas Teknologi Informasi, Institut Teknologi Sepuluh Nopember (ITS) \\ Jl. Arief Rahman Hakim, Surabaya 60111 Indonesia \\ e-mail: mahendrawathi.er@gmail.com
}

\begin{abstract}
Abstrak-Institut Teknologi Sepuluh Nopember merupakan salah satu perguruan teknik negeri yang telah menerapkan sistem informasi akademik untuk mendukung proses perkuliahan mahasiswa. Dalam menjalankan proses perkuliahan tentunya telah ditetapkan kurikulum yang bersifat standar. Namun pada kenyataannya tidak jarang ada perbedaan antara proses perkuliahan yang didefinisikan dalam kurikulum dengan proses perkuliahan yang dijalankan mahasiswa. Hal ini dapat menyebabkan proses perkuliahan mahasiswa terhambat dan menyebabkan mahasiswa lulus dengan tidak tepat waktu ataupun dengan IPK yang kurang baik.

Pemodelan proses perkuliahan dilakukan per-angkatan mahasiswa dengan menggunakan teknik process mining. Teknik process mining dipilih karena dengan menggunakan metode ini dapat diketahui pola pengambilan matakuliah suatu angkatan dari pemodelan proses yang memanfaatkan event log yang sudah didapatkan dari sistem informasi akademik ITS.

Hasil dari tugas akhir ini adalah model petri net dari proses pengambilan mata kuliah mahasiswa tiap angkatan dari awal masuk hingga menyelesaikan perkuliahan. Analisis yang didapatkan yakni yang pertama adalah banyaknya variasi alur pengambilan mata kuliah untuk setiap mahasiswa serta kinerja mahasiswa berdasarkan IPK dan lama studi, kedua adalah mengenai turunnya kinerja angkatan yang mengalami ekivalensi pada kurikulum 2004 ke 2009 namun tidak berlaku pada angkatan yang mengalami ekivalensi pada kurikulum 2009 ke 2014.
\end{abstract}

Kata kunci-Process Mining, Kurikulum, Kinerja Angkatan, Event log, Petri net

\section{PENDAHULUAN}

$K^{\prime}$ URIKULUM dalam perkuliahan menjelaskan mengenai program pembelajaran secara spesifik yang nantinya harus dilalui oleh mahasiswa. Dalam sebuah kurikulum biasanya terdapat hubungan antara satu matakuliah dengan matakuliah lain [1]. Kurikulum biasanya berganti seiring dengan berkembangnya ilmu dan teknologi. Perubahan kurikulum dilakukan untuk terus memperbaharui ilmu yang diberikan saat perkuliahan agar dapat mengikuti perkembangan zaman.

Salah satu jurusan Institut Teknologi Sepuluh Nopember Surabaya melaksanakan evaluasi dan pergantian kurikulum secara berkala antara 4-5 tahun sekali. Namun evaluasi juga dapat dilakukan jika kondisi menghendaki adanya perubahan yang disebabkan oleh beberapa hal [2,3]. Kurikulum di jurusan tersebut mengalami pergantian terakhir pada tahun 2014. Tentunya dalam perubahan kurikulum tersebut mahasiswa perlu melakukan penyesuaian dalam kegiatan perkuliahannya. Dalam penyesuaian tersebut dilakukanlah ekivalensi. Ekivalensi merupakan salah satu cara yang dilakukan untuk menyesuaikan perkuliahan mahasiswa dari kurikulum lama ke kurikulum baru.

Badan Akreditasi Nasional - Perguruan Tinggi adalah Badan Nasional yang bertugas untuk memberikan akreditasi terhadap jurusan atau program studi pada perguruan tinggi yang ada di Indonesia. Dalam memberikan akreditasinya, terdapat beberapa kriteria yang harus dinilai. Salah satu kriteria dalam penilaian akreditasi adalah standar 3 yaitu mengenai Mahasiswa dan Lulusan. Dalam melakukan penilaian dalam kriteria ini, salah satu elemen yang digunakan adalah profil lulusan yaitu mengenai kelulusan tepat waktu penyelesaian studi dan proporsi mahasiswa yang menyelesaikan studi dalam batas masa studi [4].

Dalam menghadapi pergantian kurikulum ini setiap angkatan akan mengalami permasalahan dan tantangan tersendiri. Terkadang, perubahan kurikulum ini mempengaruhi kinerja tiap angkatan dengan dampak yang berbeda tergantung kapan terjadinya perubahan kurikulum ini. Untuk perubahan kurikulum yang diterapkan di Jurusan Tersebut dapat dilihat di gambar 1 .

Dari tersebut di atas dapat dilihat bahwa jika perubahan kurikulum terjadi pada tahun 2004, 2009 dan 2014, maka angkatan yang mengalami proses ekivalensi adalah 2006, 2007 dan 2008 untuk pergantian kurikulum 2004 ke kurikulum 2009. Sedangkan angkatan 2011, 2012 dan 2013 mengalami proses ekivalensi untuk pergantian kurikulum 2009 ke kurikulum 2014. Dalam hal ekivalensi, terdapat angkatan yang memiliki kesamaan kondisi. Kesamaan angkatan 2006 dan 2011 yang mengalami perubahan kurikulum pada tahun keempatnya, 2007 dan 2012 yang mengalami perubahan kurikulum pada tahun ketiganya dan angkatan 2008 dan 2013 yang mengalami perubahan kurikulum pada tahun keduanya. Sedangkan angkatan 2004, 2005, 2009 dan 2010 tidak mengalami ekivalensi. 


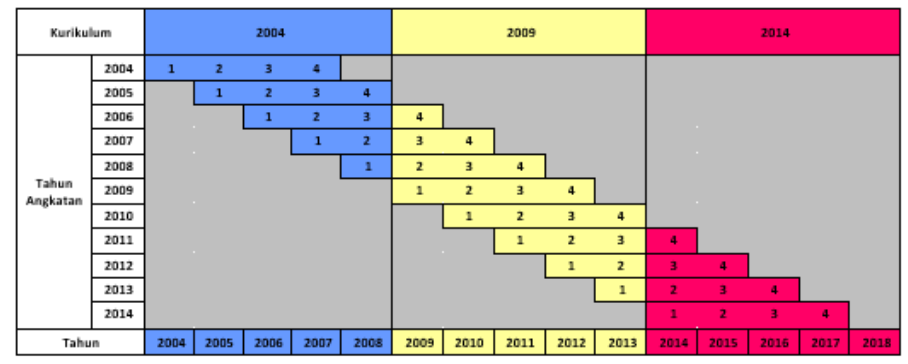

Gambar 1 Penerapan Kurikulum di Salah Satu Jurusan ITS

Integra ITS adalah Sistem Informasi Akademik yang digunakan sejak tahun 2004 oleh Institut Teknologi Sepuluh Nopember Surabaya. Integra ITS terdiri dari SI Akademik, SI SKEM, SI Penalaran, SI Beasiswa, SI Yudisium dan SI Kurikulum. Integra telah menyimpan data akademik mahasiswa, yaitu data administrasi perkuliahan mahasiswa. Data administrasi perkuliahan mahasiswa ini terdiri dari data mengenai NRP, nama mahasiswa, dosen wali, matakuliah yang diambil, dosen pengampu matakuliah, nilai matakuliah dan waktu pengambilan matakuliah. Educational event logs dapat diambil dari software edukasi yang diterapkan oleh perguruan tinggi [5]. Dengan demikian ITS melalui integra memiliki data yang nantinya bisa dibentuk menjadi educational event logs yang dapat dianalisis lebih lanjut.

Dari permasalahan tersebut akan dilakukan analisis mengenai kinerja tiap angkatan dalam menghadapi kegiatan perkuliahan dari awal hingga lulus, dampak dari ekivalensi terhadap kinerja angkatan dalam perkuliahan serta pengaruh jumlah mahasiswa terhadap kinerja angkatan. Model yang nantinya dianalisis adalah model petri net yang didapatkan dari pengolahan event log perkuliahan mahasiswa. Analisis juga akan dilakukan untuk hasil perbandingan antara tiap angkatan dalam satu kurikulum, dan tiap angkatan dalam kondisi tahun ekivalensi yang sama dalam kurikulum yang berbeda. Analisis akan dilakukan menggunakan teknik proses mining menggunakan event log yang diambil dari sistem informasi akademik dari angkatan tahun 2004 hingga 2011. Dengan mengetahui kinerja angkatan maka hasil dari analisis dapat dijadikan bahan pertimbangan dalam mempersiapkan pergantian kurikulum selanjutnya, juga dapat dijadikan bahan analisis lebih lanjut yang nantinya hasilnya dapat dijadikan petunjuk dan arahan untuk mahasiswa mengeni apa yang seharusnya dilakukan dengan benar untuk membuat kinerja angkatan menjadi baik dan apa yang seharusnya dilakukan untuk mencegah kinerja angkatan menjadi kurang baik.

\section{URAIAN PENELITIAN}

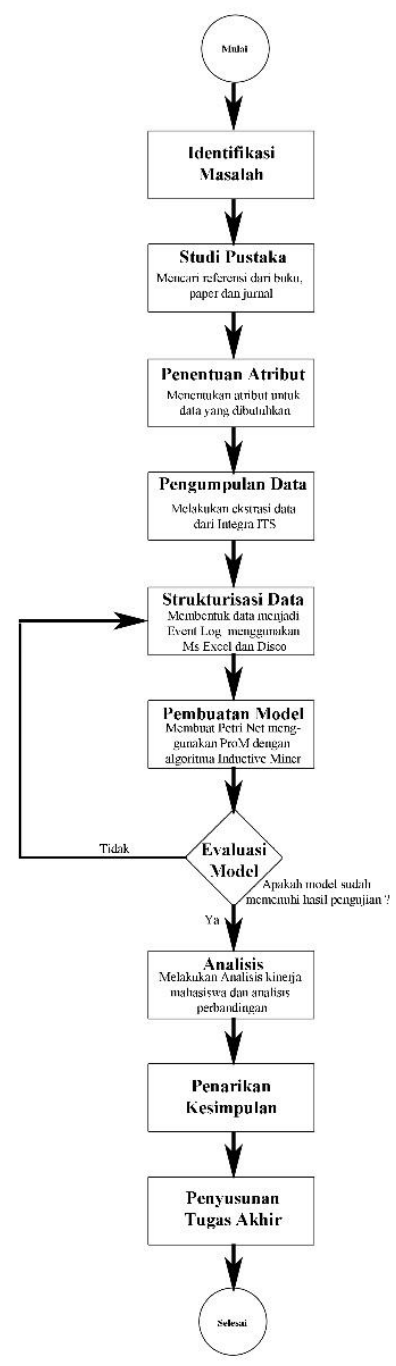

Gambar 2 Metodologi Penelitian

\section{A. Identifikasi Masalah}

Sebelum melakukan studi pustaka dilakukan penentuan topik permasalahan yang diambil. Pada penelitian tugas akhir ini penulis mengusulkan topik mengenai pemodelan dan analisis kinerja proses perkuliahan di Jurusan Sistem Informasi Institut Teknologi Sepuluh Nopember Surabaya. Selanjutnya dilakukan identifikasi masalah mengenai analisis kinerja mahasiswa dalam menghadapi kurikulum.

\section{B. Studi Literatur}

Studi Pustaka didapatkan dari pengumpulan referensi diantaranya dari narasumber, buku dan penelitian sebelumnya. Studi pustaka dilakukan untuk lebih memahami dasar-dasar teori yang berhubungan dengan permasalahan. Studi pustaka dapat membantu peneliti dalam mencari sumber yang dapat dipercaya dan latar belakang permasalahan yang diangkat dalam penelitian tugas akhir. 


\section{Penentuan Atribut Data}

Sebelum melakukan pengumpulan data, terlebih dahulu harus ditentukan data dan atribut yang akan diambil dari Sistem Informasi Akademik Integra. Data yang dibutuhkan adalah data yang memiliki id, aktivitas dan timestamp.

\section{Pengumpulan Data}

Setelah mengetahui dasar-dasar penelitian, maka dilakukan pengumpulan data untuk proses selanjutnya. Data diambil dari Sistem Informasi Akademik Integra ITS melalui Biro Akademik Kemahasiswaan dan Perencanaan. Dari proses pengumpulan data ini didapatkan data mentah yaitu berupa data mahasiswa, matakuliah yang telah diambil, kelas, nilai, dosen pengampu serta tahun pengambilan matakuliah ditambah dengan data mengenai IPK mahasiswa. Pengumpulan data ini yang nantinya akan dilakukan proses selanjutnya, yaitu menstrukturkannya.

\section{E. Strukturisasi Data}

Setelah mendapatkan data mentah, kemudian dilakukan strukturisasi data. Strukturisasi data merupakan proses pengolahan data mentah menjadi event log. Event log yang terbentuk yaitu ID berupa NRP, aktivitas berupa matakuliah, timestamp berupa tahun pengambilan matakuliah dan atribut berupa nilai IPK. Strukturisasi data akan dilakukan menggunakan Microsoft Excel dan software disco. Event log ini nantinya yang akan dibutuhkan untuk membuat model yang akan dianalisis.

\section{F. Pembuatan Model}

Setelah mendapatkan event log, maka dari data tersebut dapat dibuat pemodelan proses bisnisnya. Pembuatan model ini dilakukan dengan software ProM 6.5.1. menggunakan algoritma Inductive Miner. Keluaran dari proses ini adalah Petri net.

\section{G. Evaluasi Model}

Evaluasi dilakukan terhadap model yang didapatkan dari proses pemodelan sebelumnya, sehingga evaluasi yang dilakukan terhadap petri net hingga dihasilkan model yang valid.

\section{H. Analisis}

Dari hasil kedua proses tersebut, dilakukan analisis. Analisis yang pertama mengenai kecocokan prosedur proses bisnis perkuliahan yang berupa kurikulum yang diterapkan dengan keadaan realita yang dilakukan yang didapat dari event log yang direkam oleh Sistem Informasi Akademik. Analisis yang kedua adalah analisis untuk mengetahui kinerja dari setiap angkatan yang ada di salah satu jurusan ITS. Analisis kinerja angkatan ini dilihat dari dua indikator, yaitu mengenai kelulusan tepat waktu dan IPK dari angkatan tersebut.

\section{Penarikan Kesimpulan}

Langkah terakhir adalah menyimpulkan dari hasil analisis model yang didapat dari proses sebelumnya, sehingga dapat ditarik kesimpulan yang dapat menjawab pokok permasalahan dari penelitian Tugas Akhir.

\section{J. Penyusunan Laporan Tugas Akhir}

Setelah seluruh proses dalam penelitian mengenai analisa kinerja mahasiswa untuk tiap angkatan dilihat dari pola pengambilan mata kuliah, selanjutnya melakukan penyusunan laporan tugas akhir.

\section{HASIL DAN DISKUSI}

\section{A. Analisis Kinerja dan Pola Pengambilan Mata Kuliah}

1) Angkatan 2004

Angkatan 2004 terdiri dari 78 mahasiswa, dimana terdapat 6 mahasiswa yang terhitung belum selesai dan 72 mahasiswa telah lulus. Dari 72 mahasiswa yang lulus, terdapat 4 mahasiswa lulus dengan predikat cum laude, 61 mahasiswa lulus dengan predikat Sangat Memuaskan, 6 mahasiswa lulus dengan predikat Memuaskan dan 1 mahasiswa tanpa predikat. Sehingga terdapat $5,56 \%$ mahasiswa lulus dengan predikat cum laude dari 72 mahasiswa yang lulus.

Terdapat pola pengulangan pada semester 2 yaitu pengulangan mata kuliah KII dan penambahan mata kuliah KWN. Pada 2004 terdapat beberapa mata kuliah kurikulum 2009 yaitu PT, MLTI dan KTI. Hal ini dikarenakan terdapat 6 orang angkatan 2004 yang lulus dalam waktu lebih dari 5 tahun sehingga mengalami ekivalensi ke kurikulum 2009. Pada angkatan 2004, dari 72 case terdapat 69 varian yang berbeda sehingga hanya sedikit mahasiswa yang memiliki pola yang sama. Terdapat pola berulang pada PSSI, TKASI dan KTI. Terdapat mahasiswa yang menambah dan mengulang mata kuliah CRM, DBD, ERP, EP

\section{2) Angkatan 2005}

Angkatan 2005 terdiri dari 76 mahasiswa, dimana terdapat 18 mahasiswa yang terhitung belum selesai dan 58 mahasiswa telah lulus. Dari 58 mahasiswa yang lulus, terdapat 8 mahasiswa lulus dengan predikat cum laude, 44 mahasiswa lulus dengan predikat Sangat Memuaskan dan 6 mahasiswa lulus dengan predikat Memuaskan. Sehingga terdapat $14 \%$ mahasiswa lulus dengan predikat cum laude dari 58 mahasiswa yang lulus.

Terdapat pola mengulang dari semester 1 , yaitu pada mata kuliah AI/FD. Terdapat beberapa mata kuliah kurikulum 2009 yaitu PHP, PSDP, MPTI, KS, RBPL, IMK yang dapat dilihat pada potongan petri net gambar 6.8. dan KAL, PSI, PSSI dan TKTI yang dapat dilihat pada potongan petri net gambar 6.9. Hal ini dikarenakan terdapat 4 orang angkatan 2005 yang lulus dalam waktu lebih dari 4 tahun sehingga mengalami ekivalensi ke kurikulum 2009.

\section{3) Angkatan 2006}

Angkatan 2006 terdiri dari 111 mahasiswa, dimana terdapat 28 mahasiswa yang terhitung belum selesai dan 83 mahasiswa telah lulus. Dari 83 mahasiswa yang lulus, terdapat 7 mahasiswa lulus dengan predikat cum laude, 68 mahasiswa lulus dengan predikat Sangat Memuaskan dan mahasiswa lulus dengan predikat Memuaskan. Sehingga 
terdapat $8.43 \%$ mahasiswa lulus dengan predikat cum laude dari 83 mahasiswa yang lulus.

Terdapat pola mengulang dari semester 1, yaitu pada mata kuliah FD. Angkatan 2006 merupakan angkatan yang semua mahasiswa mengalami ekivalensi ke kurikulum 2009. Ekivalensi pada angkatan 2006 terjadi pada perkuliahan tahun ke 4. Pada petri net angkatan 2006 terdapat hal unik, yaitu terdapat percabangan tersendiri antara kurikulum 2004 dengan 2009. Hal ini dikarenakan terdapat mata kuliah yang diekivalensi. Contohnya mata kuliah SCM yang seharusnya diambil oleh angatan 2006 pada semester 7, namun karena mengalami ekivalensi, maka mata kuliah ini diekivalensi menjadi mata kuliah MRP yang ada pada semester 5 .

4) Angkatan 2007

Angkatan 2007 terdiri dari 121 mahasiswa, dimana terdapat 11 mahasiswa yang terhitung belum selesai dan 110 mahasiswa telah lulus. Dari 110 mahasiswa yang lulus, terdapat 17 mahasiswa lulus dengan predikat cum laude, 78 mahasiswa lulus dengan predikat Sangat Memuaskan dan 15 mahasiswa lulus dengan predikat Memuaskan. Sehingga terdapat $15.54 \%$ mahasiswa lulus dengan predikat cum laude dari 110 mahasiswa yang lulus.

Terdapat pola mengulang dari semester 1 , yaitu pada mata kuliah FD I dan KLI. Angkatan 2007 merupakan angkatan yang semua mahasiswa mengalami ekivalensi ke kurikulum 2009. Ekivalensi pada angkatan 2007 terjadi pada perkuliahan tahun ke 3 . Terdapat 34 mahasiswa yang menambah sks dengan mengambil mata kuliah CRM yang seharusnya diambil pada semester 6 sehingga muncul dalam petri net. Sedangkan jika tidak ada mahasiswa yang menambah mata kuliah ini maka mata kuliah CRM ini tidak akan ada dalam petri net karena mata kuliah CRM diekivalensi menjadi matakuliah PHP yang ada pada semester 3. Sementara itu 76 orang harus mengambil matakuliah PHP yang di kurikulum 2009 ada pada semester 3 pada perkuliahan semester 5-nya.

5) Angkatan 2008

Angkatan 2008 terdiri dari 170 mahasiswa, dimana terdapat 30 mahasiswa yang terhitung belum selesai dan 140 mahasiswa telah lulus. Dari 140 mahasiswa yang lulus, terdapat 17 mahasiswa lulus dengan predikat cum laude, 108 mahasiswa lulus dengan predikat Sangat Memuaskan, 12 mahasiswa lulus dengan predikat Memuaskan dan 3 mahasiswa tanpa predikat. Sehingga terdapat $12.14 \%$ mahasiswa lulus dengan predikat cum laude dari 140 mahasiswa yang lulus.

Terdapat pola mengulang dari semester 5, yaitu mata kuliah KI dan DMJ. Terdapat 26 mahasiswa yang menambah sks dengan mengambil mata kuliah KI yang seharusnya diambil pada semester 4 sehingga muncul dalam petri net. Sedangkan jika tidak ada mahasiswa yang menambah mata kuliah ini maka mata kuliah KI ini tidak akan ada dalam petri net karena mata kuliah KI diekivalensi menjadi matakuliah KI yang ada pada semester 1. Sehingga hampir sekitar 114 orang harus mengambil matakuliah KI yang ada pada semester 1 pada perkuliahan semester 3-nya.

\section{6) Angkatan 2009}

Angkatan 2009 terdiri dari 159 mahasiswa, dimana terdapat 34 mahasiswa yang terhitung belum selesai dan 125 mahasiswa telah lulus. Dari 125 mahasiswa yang lulus, terdapat 25 mahasiswa lulus dengan predikat cum laude, 84 mahasiswa lulus dengan predikat Sangat Memuaskan, 14 mahasiswa lulus dengan predikat Memuaskan dan 2 mahasiswa tanpa predikat. Sehingga terdapat $20 \%$ mahasiswa lulus dengan predikat cum laude dari 125 mahasiswa yang lulus.

Terdapat pola mengulang dari semester 4, yaitu mata kuliah STS atau RKPL atau MPTI atau MLTI atau MITI. Matakuliah KWN yang merupakan mata kuliah semester 6, sebanyak 103 mahasiswa $(82,4 \%)$ telah mengambilnya pada semester 2, 14 mahasiswa $(11,2 \%)$ telah mengambilnya pada semester 4 dan 8 mahasiswa (6.4\%) mengambilnya pada semester 6. Pada 2009 ada beberapa mata kuliah kurikulum 2014 yaitu ARSITI, KCB dan MRTI.

\section{7) Angkatan 2010}

Angkatan 2010 terdiri dari 168 mahasiswa, dimana terdapat 66 mahasiswa yang terhitung belum selesai dan 102 mahasiswa telah lulus. Dari 102 mahasiswa yang lulus, terdapat 36 mahasiswa lulus dengan predikat cum laude, 54 mahasiswa lulus dengan predikat Sangat Memuaskan, 12 mahasiswa lulus dengan predikat Memuaskan dan 1 mahasiswa tanpa predikat. Sehingga terdapat 35.29\% mahasiswa lulus dengan predikat cum laude dari 102 mahasiswa yang lulus.

Terdapat pola mengulang dari semester 2, yaitu mata kuliah PSI. Matakuliah KWN yang merupakan mata kuliah 6, sebanyak 78 mahasiswa $(76,47 \%)$ telah mengambilnya pada semester 2, 17 mahasiswa $(16,67 \%)$ telah mengambilnya pada semester 4 dan 7 mahasiswa (6.8\%) mengambilnya pada semester 6 .

8) Angkatan 2011

Angkatan 2011 terdiri dari 196 mahasiswa, dimana terdapat 67 mahasiswa yang terhitung belum selesai dan 129 mahasiswa telah lulus. Dari 129 mahasiswa yang lulus, terdapat 56 mahasiswa lulus dengan predikat cum laude, 71 mahasiswa lulus dengan predikat Sangat Memuaskan, 1 mahasiswa lulus dengan predikat Memuaskan dan 1 mahasiswa tanpa predikat. Sehingga terdapat $43.41 \%$ mahasiswa lulus dengan predikat cum laude dari 129 mahasiswa yang lulus.

Terdapat pola mengulang dari semester 4, yaitu mata kuliah SISOP, PSI dan SFB2. Dan terdapat mahasiswa yang mengambil mata kuliah Statistik yang seharusnya pada semester 4 pada semester 2-nya

\section{B. Analisis Perbandingan Angkatan}

Analisis Perbandingan Angkatan dilakukan dengan membandingkan kinerja angkatan yang berupa predikat kelulusan mahasiswa dan pola pengambilan mata kuliah yang telah dimodelkan berupa petri net. 


\section{1) Perbandingan angkatan yang menerapkan kurikulum 2004}

Angkatan 2006 memiliki jumlah kotak hitam yang lebih banyak dari angkatan lain yang berarti angkatan 2006 memiliki model dengan banyak mata kuliah yang cenderung diulang ataupun ditambah. Sedangkan angkatan 2008 memiliki jumlah pengambilan mata kuliah secara berurut yaitu sebanyak 15 mata kuliah secara berurutan. Sedangkan untuk percabangan, Angkatan 2006 memiliki 7 percabangan yang masing-masing berjumlah 6, 4, 8, 4, 7, 8, 7 mata kuliah. Hal ini dikarenakan Angkatan 2006 juga memiliki dua percabangan besar yang memisahkan mata kuliah kurikulum 2004 dan 2009. Untuk tanda panah mengulang angkatan 2006 memiliki jumlah yang paling banyak dari yang lain yaitu 6 tanda panah. Hal ini menunjukkan bahwa banyak alur mengulang mata kuliah karena pada angkatan 2006 mengalami ekivalensi sehingga mahasiswa harus mengambil mata kuliah yang diekivalensi sedangkan banyak mata kuliah kurikulum 2004 yang diekivalensi ke depan.

Dari kinerja angkatan, dengan hasil analisis model tiap angkatan pada kurikulum 2004 tidak terlihat perbedaan yang signifikan yaitu berkisar antara 3.21-3.30 untuk rata-rata IPK angkatan. Sedangkan untuk persentase lulusan tepat waktu terjadi penurunan untuk angkatan 2006 dan meningkat lagi pada 2007 dan 2008. Hal ini menunjukkan bahwa ekivalensi dari kurikulum 2004 ke kurikulum 2009 tidak mempengaruhi kinerja angkatan namun hanya pada model pengambilan mata kuliah.

\section{2) Perbandingan angkatan yang menerapkan kurikulum 2009}

Angkatan 2011 memiliki jumlah kotak hitam terbanyak dari pada 2009 dan 2010, hal ini menunjukkan bahwa angkatan 2011 memiliki banyak mata kuliah yang cenderung diulang ataupun ditambah. Untuk mata kuliah yang berurut, angkatan 2009 memiliki 18 mata kuliah yang diambil secara berurut, hal ini menunjukkan bahwa angkatan 2009 memiliki alur umum pada awal semester dengan mengikuti sesuai dengan kurikulum. Untuk percabangan, angkatan 2011 memiliki 3 percabangan dimana setiap cabangnya memiliki 4, 17 dan 4 mata kuliah. Hal ini menunjukkan bahwa angkatan 2011 memiliki banyak mata kuliah yang diambil secara bersamaan dengan variasi yang berbeda-beda. Untuk tanda panah mengulang, Angkatan 2010 memiliki 3 tanda panah mengulang yang berarti angkatan 2010 memiliki mata kuliah sebelumnya yang harus diulang.

Dari kinerja angkatan, dengan hasil analisis model tiap angkatan pada kurikulum 2004 terlihat bahwa kinerja angkatan yaitu rata-rata IPK maupun persentase lulusan tepat waktu mengalami peningkatan. Hal ini menunjukkan bahwa ekivalensi kurikulum 2009 ke kurikulum 2014 hanya berpengaruh pada model pengambilan mata kuliah saja namun tidak pada kinerja angkatan.

\section{3) Perbandingan Lintas Angkatan}

Angkatan 2004 memiliki jumlah kotak hitam yang lebih banyak dibandingkan dengan angkatan 2009 yang menunjukkan bahwa angkatan 2004 memiliki mata kuliah yang cenderung diulang ataupun ditambah lebih banyak daripada 2009. Sedangkan 2009 memiliki jumlah mata kuliah yang diambil secara berurut dibandingkan 2004. Hal ini menunjukkan bahwa Angkatan 2009 memiliki alur umum yang diambil secara berurutan sesuai dengan kurikulum. Untuk Percabangan Kurikulum 2004 memiliki 3 percabangan yang masing-masing memiliki 4, 11 dan 19 mata kuliah. Hal ini menunjukkan bahwa angkatan 2004 memiliki lebih banyak mata kuliah yang diambil secara bersamaan dengan kombinasi yang berbeda-beda. Untuk tanda panah mengulang, angkatan 2004 memiliki jumlah tanda panah yang mengulang yang menunjukkan bahwa angkatan 2004 memiliki jumlah mata kuliah yang harus diulang daripada 2009.

Angkatan 2005 memiliki jumlah kotak hitam yang lebih banyak dibandingkan dengan angkatan 2010 yang menunjukkan bahwa angkatan 2005 memiliki mata kuliah yang cenderung diulang ataupun ditambah lebih banyak daripada 2009. Sedangkan 2010 memiliki jumlah mata kuliah yang diambil secara berurut dibandingkan 2005. Hal ini menunjukkan bahwa Angkatan 2010 memiliki alur umum yang diambil secara berurutan sesuai dengan kurikulum. Untuk Percabangan Kurikulum 2005 memiliki 3 percabangan yang masing-masing memiliki 4, 9 dan 4 mata kuliah. Hal ini menunjukkan bahwa angkatan 2005 memiliki lebih banyak mata kuliah yang diambil secara bersamaan dengan kombinasi yang berbeda-beda. Untuk tanda panah mengulang, angkatan 2005 memiliki jumlah tanda panah yang mengulang yang menunjukkan bahwa angkatan 2005 memiliki jumlah mata kuliah yang harus diulang daripada 2010.

Angkatan 2006 dan 2011 memiliki jumlah kotak hitam yang hampir sama banyaknya, yaitu 41 dan 43 kotak hitam. Hal ini menunjukkan bahwa angkatan 2006 dan 2011 memiliki jumlah mata kuliah yang cenderung diulang ataupun ditambah yang hampir sama jumlahnya. Sedangkan 2011 memiliki jumlah mata kuliah yang diambil secara berurut dibandingkan 2006. Hal ini menunjukkan bahwa Angkatan 2011 memiliki alur umum yang diambil secara berurutan sesuai dengan kurikulum. Untuk Percabangan Kurikulum 2006 memiliki 7 percabangan yang masingmasing memiliki 6, 4, 8, 4, 7, 8 dan 7 mata kuliah. Hal ini menunjukkan bahwa angkatan 2006 memiliki lebih banyak mata kuliah yang diambil secara bersamaan dengan kombinasi yang berbeda-beda, ditambah angkatan 2006 memiliki banyak mata kuliah yang diekivalensi. Untuk tanda panah mengulang, angkatan 2006 memiliki jumlah tanda panah yang mengulang yang menunjukkan bahwa angkatan 2006 memiliki jumlah mata kuliah yang harus diulang daripada 2011.

\section{KESIMPULAN/RINGKASAN}

\section{A. Kesimpulan}

1. Dihasilkan 8 model pengambilan mata kuliah untuk setiap angkatan, yaitu:

a. Angkatan 2004 mengambil mata kuliah dengan urutan yang spesifik sampai dua semester pertama. Baru pada 
semester 3 muncul alternatif (percabangan) pada mata kuliah dengan urutan yang tidak spesifik (bervariasi dari satu mahasiswa dengan mahasiswa lainnya).

b. Angkatan 2005, 2006 dan 2007 adalah angkatan yang urutan pengambilan mata kuliah sudah bervariasi (tidak spesifik) dari semester 1.

c. Angkatan 2008 memiliki pengambilan mata kuliah yang berurut dan sesuai dengan kurikulum hingga 15 mata kuliah berturut-turut. Alternatif mulai muncul pada semester 3 yang menandakan bahwa mahasiswa 2008 mulai menunjukkan urutan pengambilan mata kuliah yang berbeda satu dengan lainnya.

d. Angkatan 2009 adalah angkatan dengan urutan pengambilan mata kuliah yang spesifik terbesar dari seluruh angkatan (18 mata kuliah berturut-turut) dan perbedaan urutan baru muncul mulai semester 4 .

e. Angkatan 2010 dan 2011 memiliki model pengambilan mata kuliah yang serupa dimana percabangan baru muncul pada semester 2 .

2. Perbandingan pola pengambilan mata kuliah tiap angkatan dalam satu kurikulum didapatkan beberapa hasil, yaitu:

a. Dari kurikulum 2004, angkatan 2006 memiliki jumlah percabangan dan tanda panah mengulang (loop ke depan) paling banyak yang berarti jumlah mata kuliah yang harus diulang dan atau ditambah lebih banyak dari angkatan lain. Angkatan 2008 memiliki jumlah mata kuliah yang berurutan paling banyak, yaitu hingga 15 mata kuliah berturut-turut.

b. Dari kurikulum 2009, angkatan 2011 adalah yang paling banyak mengulang atau menambah mata kuliah paling banyak dibandingkan dengan angkatan lain. Angkatan 2009 memiliki jumlah mata kuliah yang berurutan paling banyak, yaitu hingga 18 mata kuliah yang berurutan. Angkatan 2010 memiliki tanda panah mengulang lebih banyak dari 2009 dan 2011.

c. Hipotesis mengenai ekivalensi akan memiliki pengaruh yang berbeda dalam perkuliahan mahasiswa tergantung kondisi tahun ekivalensi terbukti untuk model pengambilan mata kuliah saja, namun tidak untuk kinerja angkatan.

3. Perbandingan pola pengambilan mata kuliah tiap angkatan dalam kurikulum yang berbeda dengan kondisi tahun ekivalensi yang sama didapatkan beberapa hasil, yaitu:

a. Angkatan 2004 memiliki lebih banyak percabangan dan loop ke depan yang berarti jumlah mata kuliah yang diulang dan atau ditambah lebih banyak daripada 2009. Sedangkan 2009 adalah angkatan dengan urutan mata kuliah yang paling seragam karena jumlah mata kuliah yang berurut mencapai 18 mata kuliah dan baru mulai muncul perbedaan alur pada semester 4 .

b. Angkatan 2005 memiliki lebih banyak alternatif percabangan dan tanda panah mengulang yang berarti memiliki jumlah mata kuliah yang diulang dan atau ditambah lebih banyak daripada 2010. Sedangkan 2010 memiliki jumlah mata kuliah yang berurut hingga 8 mata kuliah yang lebih banyak dari angkatan 2005.

c. Angkatan 2006 memiliki jumlah percabangan dan tanda panah mengulang lebih banyak dibandingkan 2011 yang berarti memiliki jumlah mata kuliah yang diulang dan atau ditambah lebih banyak dari angkatan 2011.

d. Hipotesis mengenai angkatan yang mengalami tahun ekivalensi yang sama akan memiliki model pengambilan dan kinerja angkatan yang sama tidak terbukti.

\section{B. Saran}

Saran yang dapat dipertimbangkan untuk pengembangan tugas akhir ini yaitu:

1. Kelengkapan angkatan sehingga setiap angkatan dapat dibandingkan pola pengambilan mata kuliah dan kinerjanya. Dalam tugas akhir ini terdapat angkatan 2009-2011 yang masih memiliki mahasiswa yang masih belum lulus.

2. Eksplorasi social network menggunakan data dosen wali atau dosen pengampu mata kuliah.

\section{DAFTAR PUSTAKA}

[1] H. Malkki and J. V. Paatero, "Curicullum Planning in Energy Engineering Education," Journal of Cleaner Production, vol. 106, no. Educational Initiative, pp. 292-299, 2015.

[2] Casmini, "Evaluasi dan Peninjauan Kurikulum BKI Berbasis KKNI," Jurnal Hisbah, vol. 11, pp. 125-144, 2014.

[3] SF Kusuma, D Siahaan, UL Yuhana,"Automatic Indonesia's questions classification based on bloom's taxonomy using Natural Language Processing a preliminary study", Proceedings on International Conference on Information Technology Systems and Innovation (ICITSI), p. 1-6, 2013

[4] B. A. N. -. P. T. Naskah Akademik Akreditasi Program Sarjana, Jakarta, 2008.

[5] J. Nesbit, Y. Xu, H. Winne and M. Zhou, "Sequential Pattern Analysis Software for Educational Event Data," Maastricht, 2008. 